DOI 10.1515/linpo-2017-0001

\title{
Object and consciousness in dialectical materialism. A contribution to the theory of social communication
}

\author{
Bolesław Andrzejewski \\ Adam-Mickiewicz-University in Poznań, Technical-University in Koszalin \\ boland@amu.edu.pl
}

\begin{abstract}
Bolesław Andrzejewski. Object and consciousness in dialectical materialism. A contribution to the theory of social communication. The Poznan Society for the Advancement of the Arts and Sciences, PL ISSN 0079-4740, pp. 7-14

The aim of the paper is to describe one of the theories of man, then of those regarding language and communication. There are many concepts related to these categories. Most of them define man as an independent being from outside, significant external influences. Dialectical materialism goes a different way in which man is a part of material world. Moreover, our language and communication have their roots and exist in the objective environment.
\end{abstract}

Keywords: communication, language, materialism (dialectical), Cassirer, Engels, Humboldt, Kant, Marx, Peirce, Sapir, Whorf

\section{Foreword}

There are many of theories of man. There also exist a great deal of concepts of language and social communication. All these categories: man, language and communication are closely connected to each other. We understand the two last phenomena as activities of human beings (also not as activities of non-human beings). The theory of man determines the kind of treatment of language and social communication.

Thus, we have in the philosophical anthropology such concepts of man as homo erectus, homo faber, homo intellectus, homo abstractus or homo symbolic. In most of these language and communication are the product of an individual. There is stressed the internal power of man, based on a priori and independent of any substantial (material) determinism. These kinds of treatment (1) reduce the human being only to one attribute and (2) they create opposition between man and the (social and natural) environment.

An example and starting point is here the philosophy of Immanuel Kant and his "Copernical turn" in the methodology. Furthermore, one can mention the language theories of Wilhelm von Humboldt, Ernst Cassirer, Edward Sapir or Benjamin L. Whorf. In 
all these cases language and communication assume a symbolic dimension and play a constructive role against the objective substance.

We have similar concepts in pragmatic philosophy. It is to tell the truth, dependent on actions in reality, although consciousness and human will eventually gain superiority against the substantial world. As C.S. Peirce (1956: 28) writes:

But the soul and meaning of thought, abstracted from the other elements which accompany it, though it may be voluntarily thwarted, can never be made to direct itself toward anything, but the production of belief [...] whatever does not refer to belief is no part of the thought itself.

A different way is taken by dialectical materialism, in which man is a strictly part of the material world. Here, in the objective circumstances begin, develop and exist his language and communication. Although both eventually become an individual/subjective feature, they both also have substantial roots and an objective dimension.

In the study below we are going to point to the presence of Marxism in one the areas of culture, namely in language and social communication. It must be pointed out that in the case of Marx and Engels the problem in this question is hidden in many works and statements which often refer to language only indirectly. Hence, issues connected with communication should be sought in deliberations of an ontological or epistemological character. Adopting this method, nevertheless, allows for the construction of the Marxist model of language and communication.

\section{Dialectical materialism on language and social communication}

Around the mid-1800s, the philosophical stage of Europe witnessed the advent of a strong philosophical and social current initiated by Karl Marx (1818-1883) and co-authored by Frederick Engels (1820-1895). It probably encompassed all continents of the earth and left a deep mark on the world's mentality. Its methodology affected numerous fields of study and dominated political and social practices in many countries. It featured ontological realism, which fostered the growth of other scopes of culture.

It must be remembered that the basic question posed by both thinkers in their works was "the question of the relation between thinking and existence" and the consequent problem of "the independence of human thinking". These are extremely important issues from the standpoint of the Marxist theory of language and communication, which in that paradigm constitute "the direct reality of thought" and which "have existed as long as consciousness". Searching then for the origins and sources of the consciousness, we naturally come across the genesis of language. The above view should not be surprising in the context of other theoretical and linguistic standpoints, which most often similarly assume the identity of thought and language (before Marx: Wilhelm von Humboldt, later Edward Sapir or Benjamin L. Whorf). What makes this view differ from the others is its adopted method, and it is this method that the sketching out of the Marxist philosophy of language and the philosophy of communication should start with.

Dialectical and historical materialism (which is what the system proposed by the above-mentioned thinkers is most frequently and adequately called) does not assume 
a ready and developed human being in the first place, all the more, when we take into account all their spiritual wealth. People become equipped with corporeality and deeply settle into the material reality. It is true that they do create their own imaginations and ideas, but do it as "real, active men, as they are conditioned by a definite development of their productive forces and of the intercourse corresponding to these, up to its furthest forms. Consciousness can never be anything else than conscious existence" (Marx \& Engels 1975: $27^{1}$ ). In another place: "Thinking and being are thus certainly distinct, but at the same time they are in unity with each other" (Marx 1962: 5812).

In other philosophical and linguistic systems people are distinguished from animals by the degree of their consciousness. For example, as the neo-Kantist Ernst Cassirer puts it, this is the ability to create symbols, hardly connected to the substantial reality, as well as the ability to use them. In dialectical materialism this difference is determined by work in the material sphere, for people "begin to distinguish themselves from animals as soon as they begin to produce their means of subsistence, a step which is conditioned by their physical organisation" (Marx 1975: 213).

In order to think, to create, as well as to speak, one first has to eat, drink, get dressed, live somewhere, etc. Thus, the suprabiological sphere has to be preceded by material activities aimed at satisfying one's biological needs. At the same time, it is important to constantly think that the activity of an individual always has a social dimension. On the one hand then, man is determined by practices in the material sphere, while on the other, by countless bonds with the rest of the society. That fact was overlooked even by Marx's outstanding master L. Feuerbach, a materialist and a naturalist in his philosophical and anthropological definitions. In his criticism of this metaphysical materialism, Marx wrote that "the human essence is no abstraction inherent in each single individual. It is the ensemble of the social relations" (Marx 1975: $7^{4}$ ).

The method of defining man, based on material practice, is successfully applied by the authors of Marxism to the philosophy of language and communication. After all, thought itself formed his way can only be expressed in the form of material currents of air, namely "language". For that reason, the latter "is practical consciousness that exists also for other men, and for that reason alone it really exists for me personally as well; language, like consciousness, only arises from the need, the necessity, of intercourse with other men (let us note the far-reaching discrepancy between those views and those of Wilhelm von Humboldt for whom language is a spontaneous emanation of an active spirit [comment by B.A.])" (Marx 1975: $32^{5}$ ).

The context of the above statement implies that people had more and more to say to each other as the production of material goods developed, as well as what followed in consequence as human relations got closer. In this respect, Marxist classicists strongly emphasise the category of "work", which, as they believe, "created man himself". The

\footnotetext{
1 www.marxists.org/archive/marx/works/1844/manuscripts/preface.htm.

2 www.marxists.org/archive/marx/works/1845/german-ideology/ch01a.htm.

3 Ibidem.

${ }^{4}$ www.marxists.org/archive/marx/works/1845/theses/theses.htm.

${ }^{5}$ www.marxists.org/archive/marx/works/1845/german-ideology/ch01a.htm.
} 
issue is paid a lot of attention by F. Engels, in whose opinion work had given man broader mental horizons and enabled him to learn about nature. By discovering new facts and improving his tools of work, man felt an increasing need to share his observations with other people. That need developed his articulatory basis, which, in the phylogenetic evolution, allowed for producing better quality and more and more intentionally articulated sounds. An important part of the human body comprise the hands, a basis for the development of both one's sensory organs and brain, as well as for the development of one's consciousness and language. Due to the evolutionary development of the hands, man could construct tools, control nature and, at the same time, create himself, his consciousness and his language. It is interesting to note Engels' observation that the development of the hands affects the development of other organs of our body, especially the brain, on the principle of evolutionary correlation. "The gradually increasing perfection of the human hand, and the commensurate adaptation of the feet for erect gait, have undoubtedly, by virtue of such correlation, reacted to other parts of the organism. However, this action has not as yet been sufficiently investigated for us to be able to do more here than to state the fact in general terms" (Engels 1972: 5276).

Some later research seems to positively verify the above idea to a great extent. It is believed that the language of gestures was a significant stage in the development of communication. Among those were gestures connected with work which, communication-wise, were the most helpful acts of behaviour, having two functions at the same time, namely productive and communicative. It was not only the impulses connected with the production processes that were sent to the hands but also those connected with the processes of the transmission of information. "It is not a coincidence" - as one researcher puts it, generalising about the discoveries in psychology and anatomy - "that the language centres in the brain, controlling the movements of the speech apparatus, are located in the direct neighbourhood of the centres which control the movements of the hand" (Albrecht 1975: 172).

In the physical sense, man thus adopts an active attitude towards the surrounding reality. Owing to his conscious exchange of energy with material objects he can change them for his purposes and adjust them for his needs. This, in turn, allows man to better adapt to the environment and, which is very important, provides a basis for auto-creation.

The activity of a subject is also related to their cognitive activity, for which practice and experimentation are the basic sources of knowledge. In his desire to find out more about a given thing, man cannot adopt a merely contemplative attitude but has to physically and mentally participate in the act of cognition in an active manner. Standing on the basis of critical realism, dialectical and historical materialism understands cognition as "a subjective reflection of the objectively existing reality". That specific "subjectivism" is underlain with many factors, such as the build of the body, the condition of one's health, concentration, culture or upbringing.

A considerable role is played here by language, which, being "the direct reality of thought", affects our way of perception. Language is one of the forms of man's behaviour and not only differentiates him from other living creatures, but also helps him direct his

${ }^{6}$ www.marxists.org/archive/marx/works/1876/part-played-labour/index.htm. 
actions better. Our knowledge is best expressed in language, which is why questions regarding the possibilities of expression and the cognitive capacity of language are so important.

This does not concern a priori conditions or the constructive values of consciousness and language, and, what follows, regarding their cognitive helplessness with regard to an external world in itself.

Marxism rejects this type of idealised attitude and accepts neither the concept of the autonomous priority of the subject with respect to the object, nor the agnosticism resulting therefrom. Although it may emphasise man's active attitude to nature and not negate a definite dose of cognitive subjectivism, these obvious facts cannot be a basis for proclaiming the unknowableness of objective things. Dialectical and historical materialism tries to overcome communicative constructivism, going beyond merely intellectual operations and referring to an objective activity. The method adopted by this system, based on the experiment and the practice of production, is supposed to enable man to overcome subjective barriers and to reach the essence of natural phenomena. The method refers to praxis thus becoming the only criterion of the truthfulness of knowledge and its linguistic expression.

Agnosticism resulting from apriorism - both cognitive and communicative - is severely criticised by Engels: "The most telling refutation of this as of all other philosophical crotchets is practice - namely, experiment and industry. If we are able to prove the correctness of our conception of a natural process by making it ourselves, bringing it into being out of its conditions and making it serve our own purposes into the bargain, then there is an end to the Kantian ungraspable 'thing-in-itself'" (Engels 1969: 3097).

Thus, language, which is the materialised content of consciousness and which uses specific concepts to "subjectify" the objectivity of the world to an extent, can make a convenient tool for exploring and describing that very world. After all, despite the acknowledgement of the cognitive activity of consciousness and language, man must not isolate himself from material existence or external stimuli. The Marxist theory of "reflection" distinguishes three stages in the process of cognition: sensory inspection, abstracting and practice. In any case, the starting point (and the means of verifying "the achievement") in the process of the creation of consciousness is the material being and human material activity. Thought developed gradually as a result of the sensory contact of our ancestors with their natural surroundings; even today its main source is sensory experience. "Sense-perception [...] must be the basis of all science - says Marx. - Only when it proceeds from sense-perception [...] - is it true science [...]. Even the element of thought itself - the element of thought's living expression - language - is of a sensuous nature" (Marx 1962: 586 ${ }^{8}$ ).

General concepts expressed in language are rooted in empirical knowledge, while the direction of their formation is of inductive nature and runs from the particular to the general. It is wrong to adopt the reverse order, that is to start with general concepts, and all the more so when those are hypostatised, a phenomenon which is connected with the

\footnotetext{
7 www.marxists.org/archive/marx/works/1886/ludwig-feuerbach/ch02.htm.

${ }^{8}$ www.marxists.org/archive/marx/works/1844/manuscripts/preface.htm.
} 
autonomisation of language. Such an approach was adopted explicitly in Plato's extreme conceptual realism. It also occurred in the views of communicative constructivism which were based on apriorism. From the Marxist perspective, it is not consciousness that determines life, but life that determines consciousness. Man must thus be perceived in his natural environment, which provides an opportunity for one to understand the cause of the formation of concepts.

The above findings do not mean, however, that man is devoid of any ideas preceding sensory activity. The authors of Marxism admit that the purposefulness of his actions is inherent in man and is simply one of the qualities which distinguish him from animals. "But what distinguishes the worst architect from the best of bees" - as we read in Das Capital - "is this, that the architect raises his structure in imagination before he erects it in reality. At the end of every labour-process, we get a result that already existed in the imagination of the labourer at its commencement" (Marx 1968: 2069).

In this respect, a stand is adopted which could conventionally be called "relative apriorism", according to which man, approaching a task, already has some definite knowledge (theory), which shows a "pure", "a priori" character with respect to a given experience. Nevertheless, there are no such things as absolutely "pure" ideas (or, consequently, words) which are completely devoid of an empirical genesis. Eventually, in the long run, consciousness and, consequently, language come from sensory experience.

In the above-outlined realistic philosophy of communication, the authors of Marxism want to free people from the ideological and manipulative violence of linguistic expressions. In the contemporary capitalism language was saturated, as they claimed, with "the spirit of the market" while all relations between people were established and explained in commercial and economic terms. An example of such a linguistic manipulation was the way of labelling workers, reported by Marx in Das Capital, who, depending on the number of their working hours, were called "full-timers" or "half-timers". In the opinion of the authors of the discussed system, the problem consists of the fact that people are not aware of the sources of ideas or linguistic expressions. In the social history, as we saw it, ideas coming from empirical knowledge used to be hypostasised and raised above reality. Given this, and used by skilful manipulators of the word, they often played a decisive role in forming consciousness and controlling behaviours. To give an example, we could point to Feuerbach's definition of religion as man's "relationship" with the surrounding reality. The thinker was certain that it was enough to understand the etymology of the word "religion" in order to thus "repair" man and to consequently repair social relations. Such an approach provided a basis for Marx's criticism. The same could be said about the pragmatic attitude, in which messages as such are neither true nor false. Their truthfulness or falsehood can only be determined by specific circumstances in which "the truth happens to the idea". It is easy to notice that the meaning of "pragmatic" messages differs from that of "classical" truthfulness, which recognises "correspondence between thought/messages and things".

The authors of the dialectical and historical materialism took a stand against the ideological dominance of language over the reality. They claim boldly: "Hitherto men have

\footnotetext{
${ }^{9}$ www.marxists.org/archive/marx/works/1867-c1/index.htm.
} 
constantly made up for themselves false conceptions about themselves, about what they are and what they ought to be. They have arranged their relationships according to their ideas... The phantoms of their brains have got out of their hands... Let us liberate them from the chimeras, the ideas, dogmas, imaginary beings under the yoke of which they are pining away. Let us revolt against the rule of thoughts" (Marks \& Engels 1975: 13 ${ }^{10}$ ).

\section{Conclusion}

Marxism therefore makes a strong methodological basis for the assessment of many philosophical and linguistic standpoints, which mainly mean idealistic perspectives ignoring the material reality to a great extent. Apart from the above-mentioned views, we could also point to the well-developed neo-Kantian tradition, in which cultural products ("phenomena") are the opposites of "things in themselves", which are closed and incomprehensible to man. Kantian apriorism gave rise to Ernst Cassirer's "philosophy of symbolic forms", which proposed the existence of linguistic "symbols", abstracted from the substantial reality. In the 20th century, within the idealistic current the concept of linguistic relativism was developed, best formulated in the so-called Sapir-Whorf- hypothesis. As in the case of symbolism, also in accordance with the intention of linguistic relativism, reality is barely represented in communication structures. From these perspectives, reality is simply constructed by means of linguistic expression.

The above and other similar idealistic views come in for criticism from the Marxist philosophy. As a Polish supporter of the Marxist methodology, Adam Schaff put it: "what Whorf presents can be philosophically categorised as idealism, or worse, as extreme relativism which rules out the possibility of objective truth" (Schaff 1967: 106).

Summing up, the realistic aspect of the Marxist and neo-Marxist concept of language and communication should be emphasised once again. This concept deviates from a prio$r i$ and constructivist perspectives which autonomise consciousness and its expression, namely language. In dialectical and historical materialism both phenomena are deeply rooted in reality and, in consequence, are a (subjective) reflection thereof. Such an approach, as intended by its representatives, was supposed to de-ideologise communication, save its users from the manipulative influence of language constructs and bring the latter closer to Aristotelian truthfulness.

\section{References}

Albrecht, Erhard. 1975. Language and Philosophy. (Sprache und Philosophie) Berlin: VEB Deutscher Verlag der Wissenshaften.

Engels, Fryderyk. 1972. The Part Played by Labour in the Transition from Ape to Man. (Rola pracy w procesie uczłowieczenia małpy) In MED (Marx-Engels Works), vol. 20. Warszawa: Książka i Wiedza.

Engels, Fryderyk. 1969. Ludwig Feuerbach and the End of Classical German Philosophy. (Ludwig Feuerbach i zmierzch klasycznej filozofii niemieckiej) In $M E D$, vol. 21. Warszawa.

${ }^{10}$ www.marxists.org/archive/marx/works/1845/german-ideology/index.htm. 
Marx, Karol. 1962. Economic and Philosophic Manuscripts of 1884. (Rękopisy ekonomiczno-filozoficzne 1884) In $M E D$, vol. 1. Warszawa.

Marx, Karol. 1968. Capital. (Kapitał) In MED, vol. 23. Warszawa.

Marx, Karol. 1975. Theses on Feuerbach. (Tezy o Feuerbachu) In MED, vol. 3. Warszawa.

Marx, Karol \& Engels, Fryderyk. 1975. The German Ideology. (Ideologia niemiecka) In MED, vol. 3. Warszawa.

Peirce, Charles Sanders. 1956. How to Make Our Ideas Clear. In Buchler, Justus (ed.), The Philosophy of Peirce. London: Routledge \& Kegan.

Schaff, Adam. 1967. Language and cognition. (Język i poznanie) Warszawa: PWN.

\section{Links used in the text}

www.marxists.org/archive/marx/works/1844/manuscripts/preface.htm.

www.marxists.org/archive/marx/works/1845/german-ideology/ch01a.htm.

www.marxists.org/archive/marx/works/1845/theses/theses.htm.

www.marxists.org/archive/marx/works/1867-c1/index.htm.

www.marxists.org/archive/marx/works/1886/ludwig-feuerbach/ch02.htm. 